\title{
Mechanical properties of high strength aluminium alloy at elevated temperatures
}

DOI:

10.1002/cepa.334

\section{Document Version}

Accepted author manuscript

Link to publication record in Manchester Research Explorer

\section{Citation for published version (APA):}

Su, M., \& Young, B. (2017). Mechanical properties of high strength aluminium alloy at elevated temperatures. ce/papers. https://doi.org/10.1002/cepa.334

\section{Published in:}

ce/papers

\section{Citing this paper}

Please note that where the full-text provided on Manchester Research Explorer is the Author Accepted Manuscript or Proof version this may differ from the final Published version. If citing, it is advised that you check and use the publisher's definitive version.

\section{General rights}

Copyright and moral rights for the publications made accessible in the Research Explorer are retained by the authors and/or other copyright owners and it is a condition of accessing publications that users recognise and abide by the legal requirements associated with these rights.

\section{Takedown policy}

If you believe that this document breaches copyright please refer to the University of Manchester's Takedown Procedures [http://man.ac.uk/04Y6Bo] or contact uml.scholarlycommunications@manchester.ac.uk providing relevant details, so we can investigate your claim.

\section{OPEN ACCESS}




\title{
Mechanical properties of high strength aluminium alloy at elevated temperatures
}

\author{
Mei-Ni Su, ${ }^{*}$, Ben Young ${ }^{\mathrm{b}}$ \\ ${ }^{\text {a }}$ Shenzhen University, Dept. Civil Engineering, China \\ sumeinimay@szu.edu.cn \\ ${ }^{\mathrm{b}}$ Department of Civil Engineering, The University of Hong Kong, Hong Kong, China \\ young@hku.hk
}

\begin{abstract}
The mechanical properties of extruded aluminium alloys behave differently as temperature rises. Accurate prediction of the mechanical properties of aluminium alloys at elevated temperatures is necessary for determining the load-carrying capacity of structures under fire conditions. This study focuses on the effects of high strength aluminium alloy 6061-T6 at elevated temperatures. The melting point of aluminium alloy $6061-\mathrm{T} 6$ is found to be approximately $650{ }^{\circ} \mathrm{C}$. Therefore, tensile coupon tests were conducted at different temperatures ranging from approximately 24 to $600 \circ \mathrm{C}$ for both steady and transient state tests. The material properties of aluminium alloy 6061-T6 with plate thickness of $4.5 \mathrm{~mm}$ were obtained. The tests were performed using servo-controlled hydraulic testing machine equipped with MTS 653 furnace. The Young's modulus, the yield strength (i.e. the $0.2 \%$ proof stress) and the ultimate strength versus different temperatures are also plotted and compared with the predictions from the American Aluminum Design Manual and Eurocode EN1999-1-2. The comparisons of the results are plotted and summarized in this paper, together with a detailed discussion. It is found that both the American Aluminum Design Manual and Eurocode generally provide conservative predictions for the high strength aluminium alloys at elevated temperatures.
\end{abstract}

Keywords: Aluminium alloys, material property, elevated temperatures, design codes

\section{INTRODUCTION}

The structural behaviour of aluminium alloy members is highly dependent on its material properties. Determination of material properties for metallic materials, especially the Young's modulus, the yield stress $(0.2 \%$ proof stress), the ultimate stress and the ultimate strain, plays a solid foundation in structural design. In order to investigate the performance of aluminium alloy structures in fire, it is necessary to understand the material properties at high temperatures. In addition, material properties are greatly affected by temperature, and special attention must be given by the designer for extreme conditions above $200{ }^{\circ} \mathrm{F}\left(93^{\circ} \mathrm{C}\right)$ [1]. However, previous researches on the material behaviour have been mainly focused on hot-rolled steel and cold-formed steel, while limited data is available for the mechanical properties of aluminium alloys at elevated temperatures.

The reduction factors for aluminium alloy mechanical properties at elevated temperatures have been recommended in Session 4.2.3 of the American Aluminum Design Manual (ADM) [2] and also Session 3.2 of European Code 9 EN 1999-1-2 [3]. In addition, the temperature effects on the material properties of different aluminium alloys have been investigated, including aluminium alloy A319 [4], cold deformed aluminium 7075 [5], aluminium alloys 7075 and 2124 [6] as well as aluminium alloy 2024T3 [7]. Both tests and modelling were conducted in these researches. The constitutive model at elevated temperatures has also been proposed.

In this study, both steady and transient state test methods are used in tensile coupon tests of aluminium alloys. In steady state tests, the test specimen is heated up to a specified temperature 
then a tensile test is carried out, whereas in transient state tests the load remains constant and the temperature rises until the test specimen fails. The experimental program was conducted to obtain the material properties of aluminium alloys at elevated temperatures up to $600^{\circ} \mathrm{C}$. This paper presents the details of the tests. The test specimens were extruded from aluminium alloys 6061-T6 with plate thickness of $4.5 \mathrm{~mm}$. The mechanical properties such as the Young's modulus, the yield stress ( $0.2 \%$ proof stress), the ultimate stress and the ultimate strain were determined from the test results of both steady and transient state test methods. The reduction factors for aluminium alloy mechanical properties at elevated temperatures obtained from the tests are compared with the design values from the American Aluminum Design Manual (ADM) [2] and European Code 9 EN 1999-1-2 [3].

\section{EXPERIMENTAL PROGRAMME}

\subsection{Test specimens}

Tensile coupon tests were conducted at elevated temperatures to determine the material properties of aluminium alloys. The test specimens were prepared from aluminium alloy rectangular hollow sections (RHS) with nominal dimension (Width $\times$ Height $\times$ Thickness) $70 \mathrm{~mm} \times 55 \mathrm{~mm} \times 4.5 \mathrm{~mm}$. The temper of the material was high strength aluminium alloy 6061-T6. The dimensions of coupon specimens conformed to the Australian Standard AS 2291 [8] and the American Standard ASTM E 21 [9] for the tensile testing of metals at elevated temperatures using a 6-mm wide coupon and a gauge length of $34 \mathrm{~mm}$, while the total length of the coupon specimen was $480 \mathrm{~mm}$, as shown in Fig. 1.

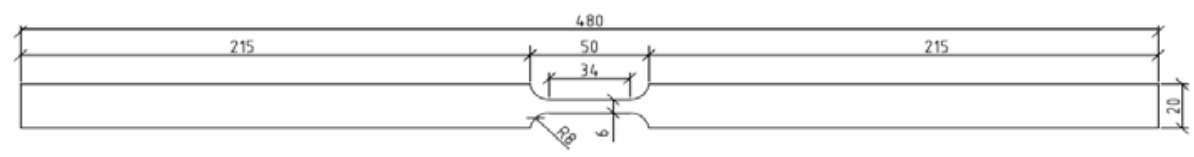

Fig. 1. Dimension of the coupon

The specimens were labelled such that the temper of aluminium alloys, the test method and the nominal temperature could be identified. For example, in the label H-S-T200, the first letter indicates the temper of aluminium alloy 6061-T6, which is considered as high strength aluminium alloys. The second letter represents the test method, where "S" represents steady state test. The last part of the label indicates the nominal temperature $\left(200^{\circ} \mathrm{C}\right.$ for the example) that the steady state test was conducted.

If the location of fracture is outside the gauge length of a specimen, meaning that the extensometer could not capture all of the strain near failure. Hence, the strains at ultimate strength and fracture could not be accurately measured and these values were not reported. These specimens are labelled by the letter " $R$ " followed by a number showing the number of tests to identify the specimens failed outside the gauge length of the coupon specimens.

\subsection{Test set-up}

An MTS testing machine was used to conduct the coupon tests. The MTS high temperature furnace with a maximum temperature of $1400^{\circ} \mathrm{C}$ was used to specify the required temperatures during testing, with an accuracy of $1^{\circ} \mathrm{C}$. There are three heating elements located at the upper, middle and lower parts on each of the two sides of the furnace. Three internal thermal couples were located inside the furnace to measure the air temperature, and three external thermal couples were also attached at the mid-length of the coupon specimen to measure the temperature of the specimen. The test set-up is shown in Fig. 2. The calibrated extensometer of $25 \mathrm{~mm}$ gauge length with the range limitation of $\pm 2.5 \mathrm{~mm}$ was mounted onto the specimens to measure the longitudinal strain during the tests. For specimens with large elongation under high temperatures, the strain may exceed the 
range limit of the extensometer. The extensometer was reset manually when it approached approximately $80 \%$ of the range limit during testing to avoid any damage to the apparatus. The actual specimen temperature was obtained by the average value of the specimen temperatures measured by the three external thermal couples at the beginning, middle and end of each steady state test. It was found that the coupon specimens maintained the specified temperatures throughout the tests.

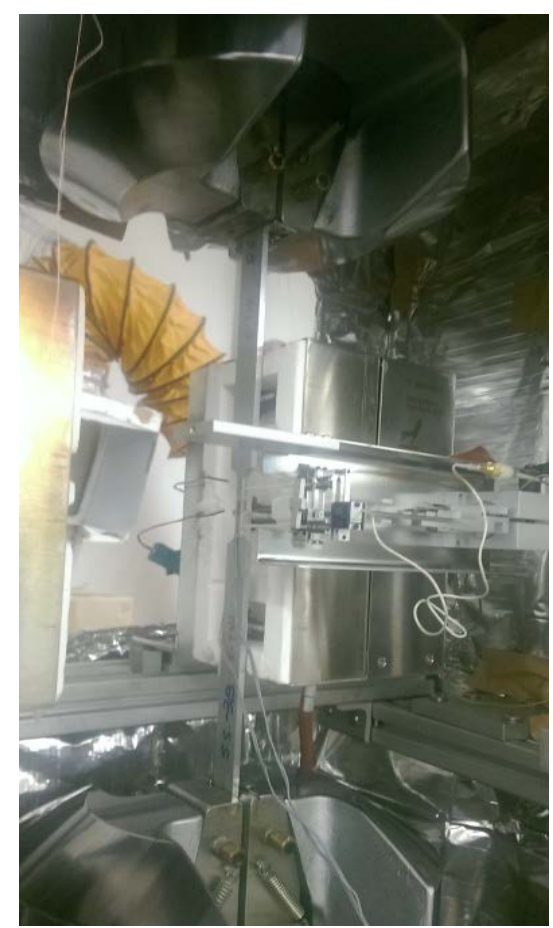

Fig.2. Test set-up of tensile coupon test at elevated temperatures

\subsection{Steady state tests}

In the steady state tests, a specimen is heated up to a specified temperature and then loaded until it fails. The temperature is maintained when the tensile load is applied during testing. Coupons extracted from each hollow section are loaded under 10 different nominal temperatures from 24 to $600^{\circ} \mathrm{C}$ with an interval of $50^{\circ} \mathrm{C}$ or $100^{\circ} \mathrm{C}$. Firstly, the upper end of the specimen was gripped, and the lower end of the specimen is free to expand during the heating process until it reaches a specified temperature. When the temperature on the specimen, which is measured by the external thermal couple, is stabilized at the specified temperature for 10 mins, the lower end of the specimen is then gripped. Secondly, tensile load is applied to the specimen by displacement control with a constant loading rate of $0.3 \mathrm{~mm} / \mathrm{min}$ until it fails. The strain rate of the tests measured by the extensometer conformed to the Australian Standard AS 2291 [8] and American Standard ASTM E 21 [9]. A total of 15 coupon specimens were tested using steady state test method.

\subsection{Transient state tests}

In the transient state tests, a specimen is subjected to a specified tensile stress while the temperature increases until the specimen fails. The nominal stress levels in this test programme were $0,80,100$, 170, 200 and $220 \mathrm{MPa}$. Load control was used in the transient state tests so that a specified stress level can be maintained during the tests. The air temperatures in the furnace increased in the heating rate of $15^{\circ} \mathrm{C} / \mathrm{min}$ until the specimen fails. The specimen temperatures were measured by the external thermal couples throughout the tests. The test results of the transient state tests were converted to the stress-strain curves of the specimens at different specimen temperatures. The load level of $0 \mathrm{MPa}$ is to measure the thermal elongation of the specimens at elevated temperatures. The lower end of the specimen was free to expand, while the temperature increased from 24 to $200^{\circ} \mathrm{C}$ in the heating rate of $15^{\circ} \mathrm{C} / \mathrm{min}$. The thermal elongation is recorded by the extensometer mounted on 
the specimen during heating. A total of 10 coupon specimens were tested under transient state test method.

\section{RESULTS AND DISCUSSION}

\subsection{Steady state}

For steady state tests, the material properties measured at room (ambient) temperature including the Young's modulus $(E)$, the $0.01 \%$ proof stress $\left(f_{0.01}\right)$, the yield strength (i.e. $0.2 \%$ proof stress) $\left(f_{\mathrm{y}}\right)$, the ultimate tensile strength $\left(f_{\mathrm{u}}\right)$, the elongation at ultimate strength $\left(\varepsilon_{\mathrm{u}}\right)$ of a gauge length of $25 \mathrm{~mm}$, and the Ramberg-Osgood parameter (n) using the Ramberg-Osgood expression $n=\ln (0.01 / 0.2) / \ln \left(f_{0.01} / f_{\mathrm{y}}\right)$ are summarized in Table 1 . It is well known that the material properties reduce as the temperature increases. The reduction factors of the Young's modulus $\left(E_{\mathrm{T}} / E\right)$, the $0.01 \%$ proof stress $\left(f_{0.01, \mathrm{~T}} / f_{0.01}\right)$, the yield stress $\left(f_{\mathrm{y}, \mathrm{T}} / f_{\mathrm{y}}\right)$, the ultimate stress $\left(f_{\mathrm{u}, \mathrm{T}} / f_{\mathrm{u}}\right)$ and the ultimate strain $\left(\varepsilon_{\mathrm{u}, \mathrm{T}} / \varepsilon_{\mathrm{u}}\right)$ determined from the ratio of material properties at elevated temperatures to those at room temperature are summarized in Table 2. Some specimens failed outside the gauge length of the coupon specimens, and therefore the ultimate strains and the strains at fracture for these specimens are not reported. The failed coupon specimens at different temperatures are shown in Fig. 3.

Table 1. Material properties at room temperature obtained from steady state tests and converted from transient state tests

\begin{tabular}{lcccccc}
\hline Specimen & $\begin{array}{c}E \\
(\mathrm{GPa})\end{array}$ & $\begin{array}{c}f_{0.01} \\
(\mathrm{MPa})\end{array}$ & $\begin{array}{c}f_{y} \\
(\mathrm{MPa})\end{array}$ & $\begin{array}{c}f_{u} \\
(\mathrm{MPa})\end{array}$ & $\begin{array}{c}\mathcal{E}_{\mathrm{u}} \\
(\%)\end{array}$ & $n$ \\
\hline \hline Static state test & 69.5 & 163.3 & 199.9 & 232.3 & 6.7 & 15 \\
Transient state test & 66.7 & 198.0 & 219.5 & --- & --- & 29 \\
\hline
\end{tabular}

Table 2. Reduction factors of material properties at elevated temperatures obtained from steady state tests

\begin{tabular}{lccccc}
\hline Specimen & $E_{\mathrm{T}} / E$ & $f_{0.01, \mathrm{~T}} / f_{0.01}$ & $f_{\mathrm{y}, \mathrm{T}} / f_{\mathrm{y}}$ & $f_{\mathrm{u}, \mathrm{T}} / f_{\mathrm{u}}$ & $\varepsilon_{\mathrm{u}, \mathrm{T} /} \varepsilon_{\mathrm{u}}$ \\
\hline \hline H-S-T100 & 0.92 & 0.94 & 0.98 & 0.97 & 1.03 \\
H-S-T200 & 0.91 & 0.72 & 0.88 & 0.85 & 0.87 \\
H-S-T250 & 0.85 & 0.65 & 0.88 & 0.82 & 0.70 \\
H-S-T300 & 0.84 & 0.86 & 0.91 & 0.81 & 0.53 \\
H-S-T350 & 0.79 & 0.82 & 0.82 & 0.73 & 0.42 \\
H-S-T350-R1 & 0.84 & 0.95 & 0.89 & 0.78 & --- \\
H-S-T400 & 0.75 & 0.70 & 0.70 & 0.63 & 0.34 \\
H-S-T400-R1 & 0.80 & 0.80 & 0.75 & 0.66 & --- \\
H-S-T450 & 0.78 & 0.51 & 0.53 & 0.47 & 0.27 \\
H-S-T500 & 0.62 & 0.38 & 0.40 & 0.37 & 0.28 \\
H-S-T500-R1 & 0.53 & 0.27 & 0.31 & 0.29 & --- \\
H-S-T500-R2 & 0.52 & 0.29 & 0.33 & 0.31 & --- \\
H-S-T500-R3 & 0.61 & 0.30 & 0.31 & 0.29 & --- \\
H-S-T600 & 0.23 & 0.08 & 0.09 & 0.09 & 0.04 \\
H-S-T600-R1 & 0.36 & 0.07 & 0.06 & 0.06 & --- \\
\hline
\end{tabular}




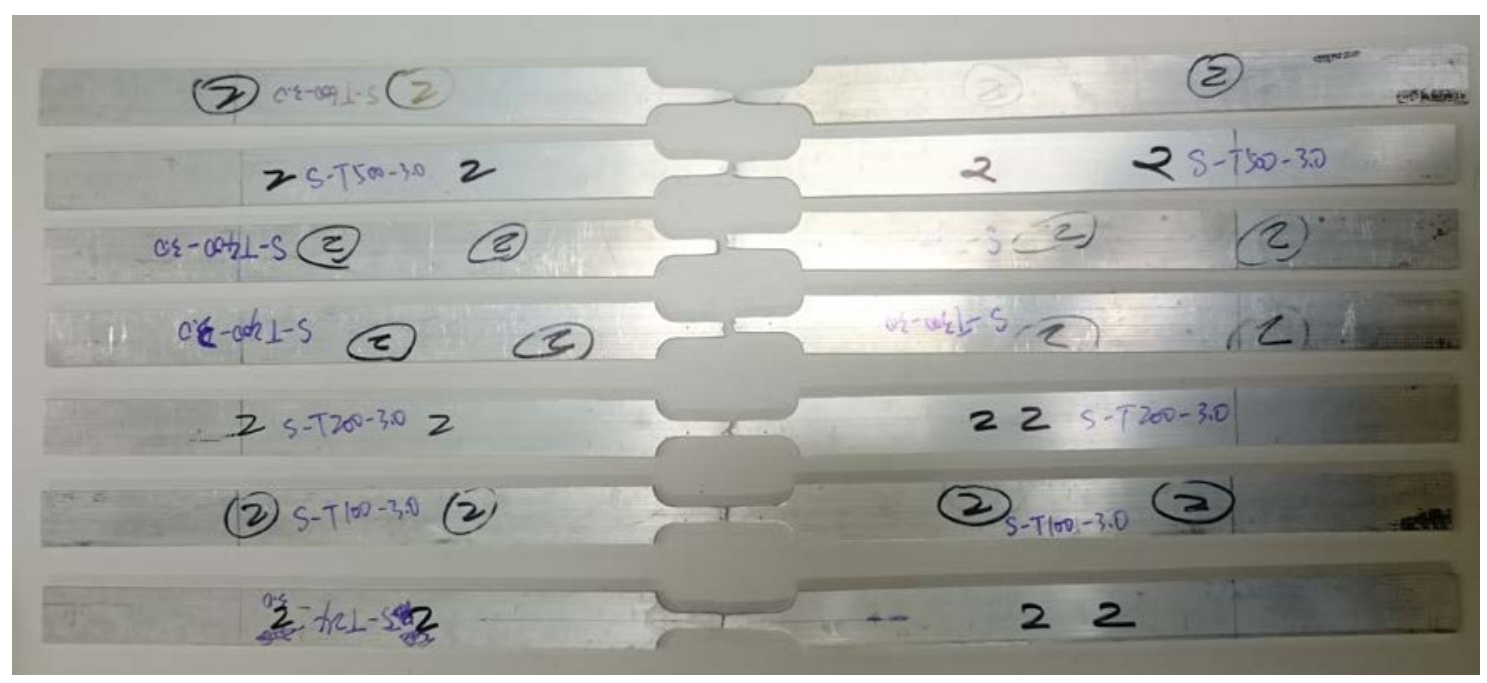

Fig. 3. Coupon specimens after tests at failure for different temperatures.

\subsection{Transient state}

For transient state tests, the test results were converted into stress-strain curves, as shown in Fig.4. The specimens were loaded under 6 different stress levels up to $220 \mathrm{MPa}$, which were maintained throughout the tests. The strains under a specified stress level were measured as the temperature increases until the failure of the specimen. The material properties obtained from the stress-strain curves from transient state test results under room temperature are summarized in Table 1, using the curves as shown in Fig. 4. The reduction factors $\left(E_{\mathrm{T}} / E, f_{0.01, \mathrm{~T}} / f_{0.01}\right.$ and $\left.f_{\mathrm{y}, \mathrm{T}} / f_{\mathrm{y}}\right)$ for the coupons are summarized in Table 3. It should be noted that the strain increased quickly near the failure load under load control. The extensometer was removed before the fracture of the coupon specimens in order to avoid the damage of the extensometer. Therefore, the ultimate strain $\left(\varepsilon_{\mathrm{u}}\right)$ and strain at fracture $\left(\varepsilon_{\mathrm{f}}\right)$ cannot be recorded in transient state tests. In addition, the ultimate strengths $\left(f_{\mathrm{u}}\right)$ may not occur at the 6 specified stress levels in the transient state tests.

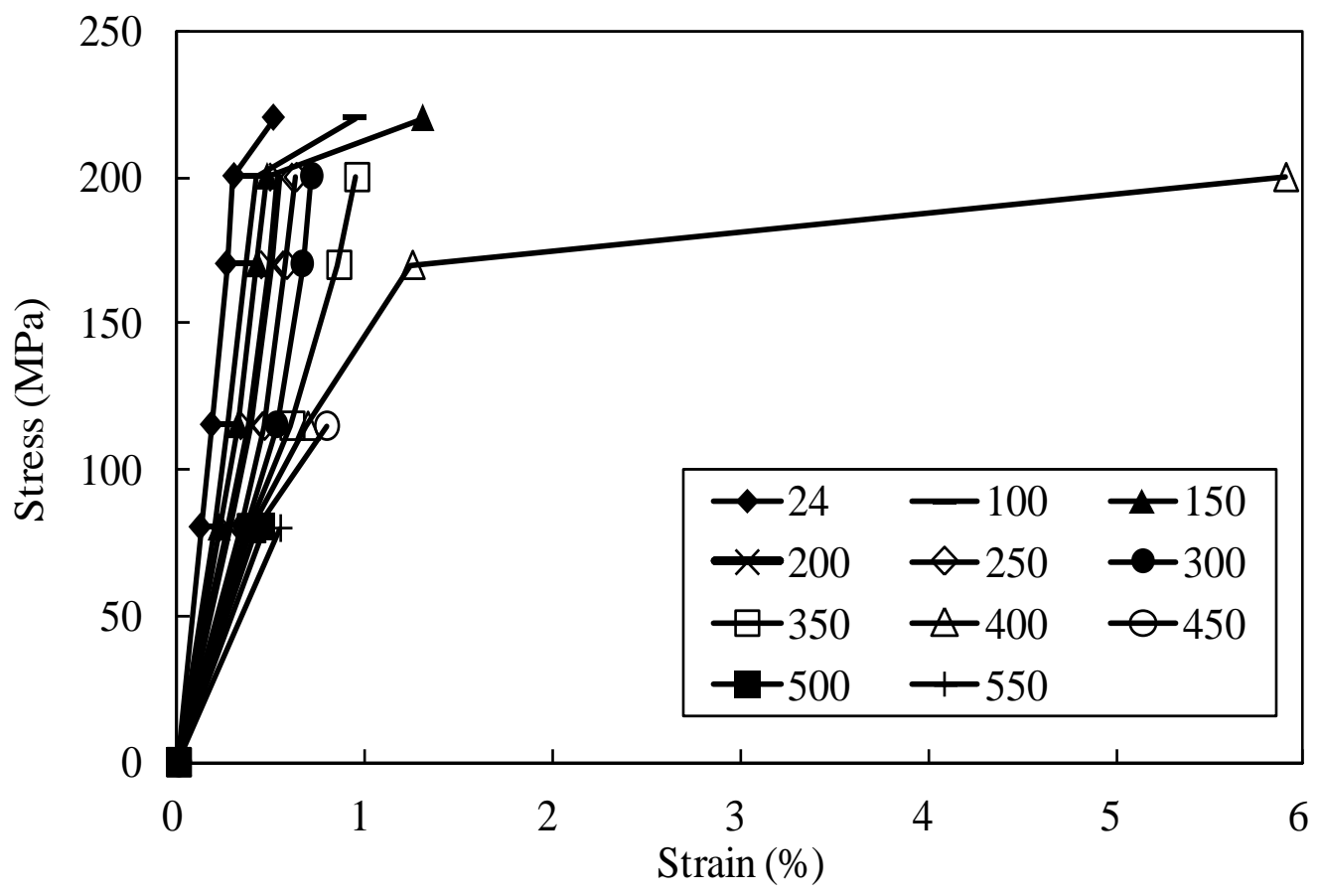

Fig. 4. Stress-strain curves at different temperatures obtained from coupon tests in transient state. 
Table 3. Reduction factors of material properties at elevated temperatures stress-strain curves converted from transient state test results

\begin{tabular}{cccc}
\hline $\begin{array}{c}\text { Temperature } \\
\left({ }^{\circ} \mathrm{C}\right)\end{array}$ & $E_{\mathrm{T}} / E$ & $f_{0.01, \mathrm{~T}} / f_{0.01}$ & $f_{\mathrm{y}, \mathrm{T}} / f_{\mathrm{y}}$ \\
\hline \hline 100 & 0.85 & 0.99 & 0.95 \\
150 & 0.81 & 0.98 & 0.93 \\
200 & 0.76 & --- & 0.91 \\
250 & 0.70 & --- & 0.84 \\
300 & 0.61 & --- & --- \\
350 & 0.55 & --- & --- \\
400 & 0.31 & 0.40 & 0.59 \\
450 & 0.28 & 0.40 & 0.52 \\
500 & 0.26 & --- & --- \\
550 & 0.22 & --- & --- \\
\hline
\end{tabular}

\section{COMPARISON OF TEST RESULTS WITH EXISTING DESIGN RULES}

The reduction factors of the Young's modulus, the yield strength $(0.2 \%$ proof stress) and the ultimate strength for high strength aluminium alloy under both steady state and transient state tests at elevated temperatures obtained from this study are compared with design values using the American Aluminum Design Manual (ADM) [2] and European Code 9 EN 1999-1-2 [3]. The reduction factors of the Young's modulus $\left(E_{\mathrm{T}} / E\right)$, the yield strength $\left(f_{\mathrm{y}, \mathrm{T}} / f_{\mathrm{y}}\right)$ and the ultimate strength $\left(f_{\mathrm{u}, \mathrm{T}} / f_{\mathrm{u}}\right)$ obtained from both steady and transient state test methods are plotted against the specimen temperatures in Figs 5-7, respectively.

The reduction factors of the Young's modulus, the yield strength and the ultimate strength at elevated temperatures for different tempers of aluminium alloys are provided in Tables 4.1-4.2 of the American Aluminum Design Manual (ADM) [2] as well as Tables 1a and 2 of the Eurocode EN 1999-1-2 [3]. The reduction factors in both codes are provided for discrete temperatures only. According to the codes, linear interpolation was adopted to obtain the reduction factors corresponding to the actual temperatures on the test specimens. The comparisons of the reduction factors are summarized in Table 4.

For the Young's modulus, the predictions by ADM are conservative for the steady state tests, whereas generally slightly conservative for the transient state tests. The mean values $\frac{\left(E_{T} / E\right)_{t e s t}}{\left(E_{T} / E\right)_{A D M}}$ equal to 2.39 and 1.07 as well as the coefficients of variation (COV) were found to be 0.628 and 0.414 for the steady state test results and the transient state test results, respectively. The predictions by EN 1999-1-2 have similar mean values $\frac{\left(E_{T} / E\right)_{\text {test }}}{\left(E_{T} / E\right)_{E N 1999}}$ of 2.42 and 1.07 , as well as the COV of 0.590 and 0.393 for the steady state test results and the transient state test results, respectively. For both the yield stress and the ultimate stress, the ADM and EN 1999 predictions are significantly conservative. The high values of COV showed that the comparisons are quite scattered, in particular for the yield stress obtained from the transient state tests being 1.131 and 1.097 for the ADM and EN 1999, respectively, whereas the COV of the ultimate stress prediction is found to be 0.700 for the ADM. From the comparisons, it is found that these two existing design rules cannot provide accurate predictions of the Young's modulus, the yield stress and the ultimate stress for high strength aluminium alloy at elevated temperatures. 


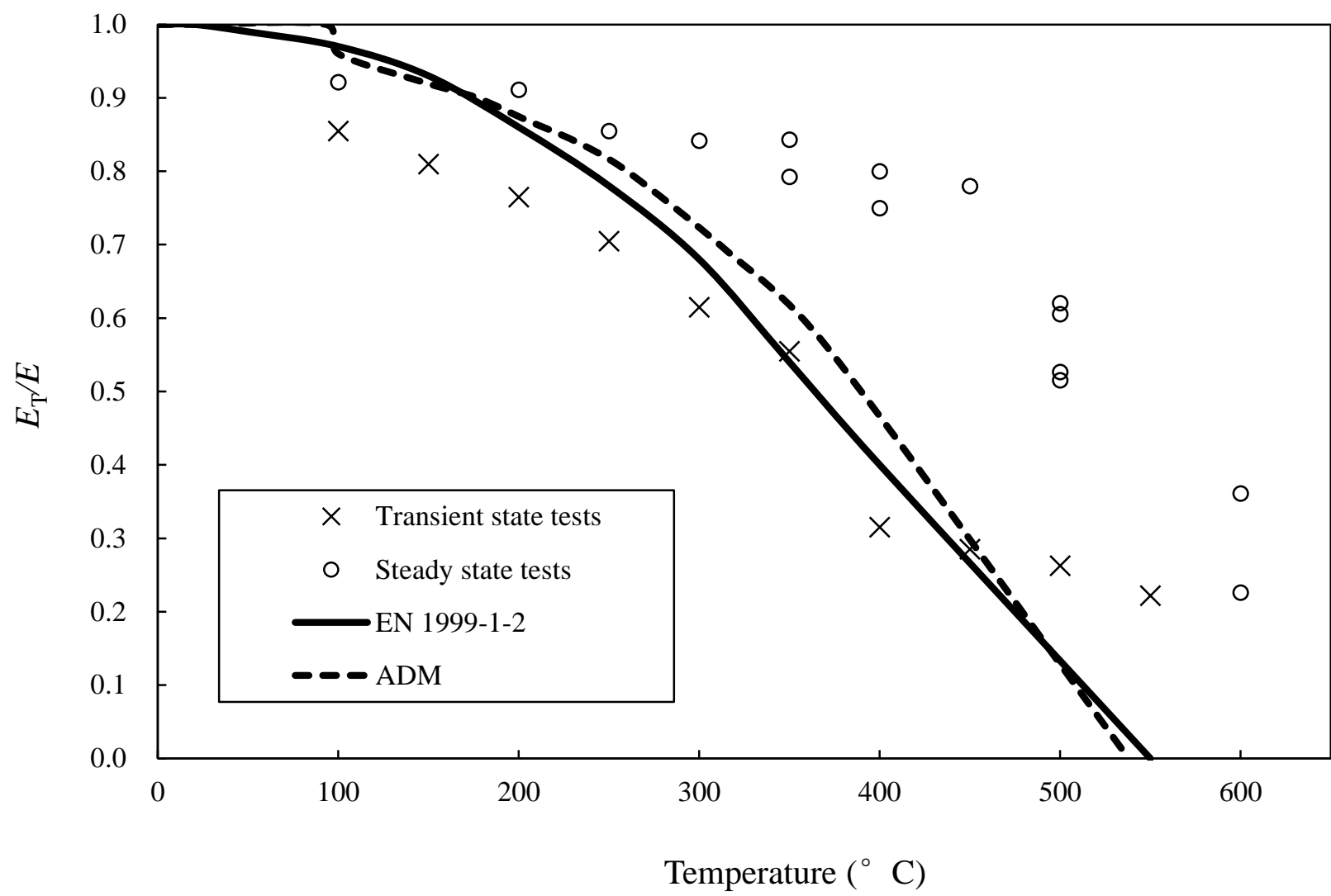

Fig. 5. Comparison of the Young’s modulus obtained from design rules and test results.

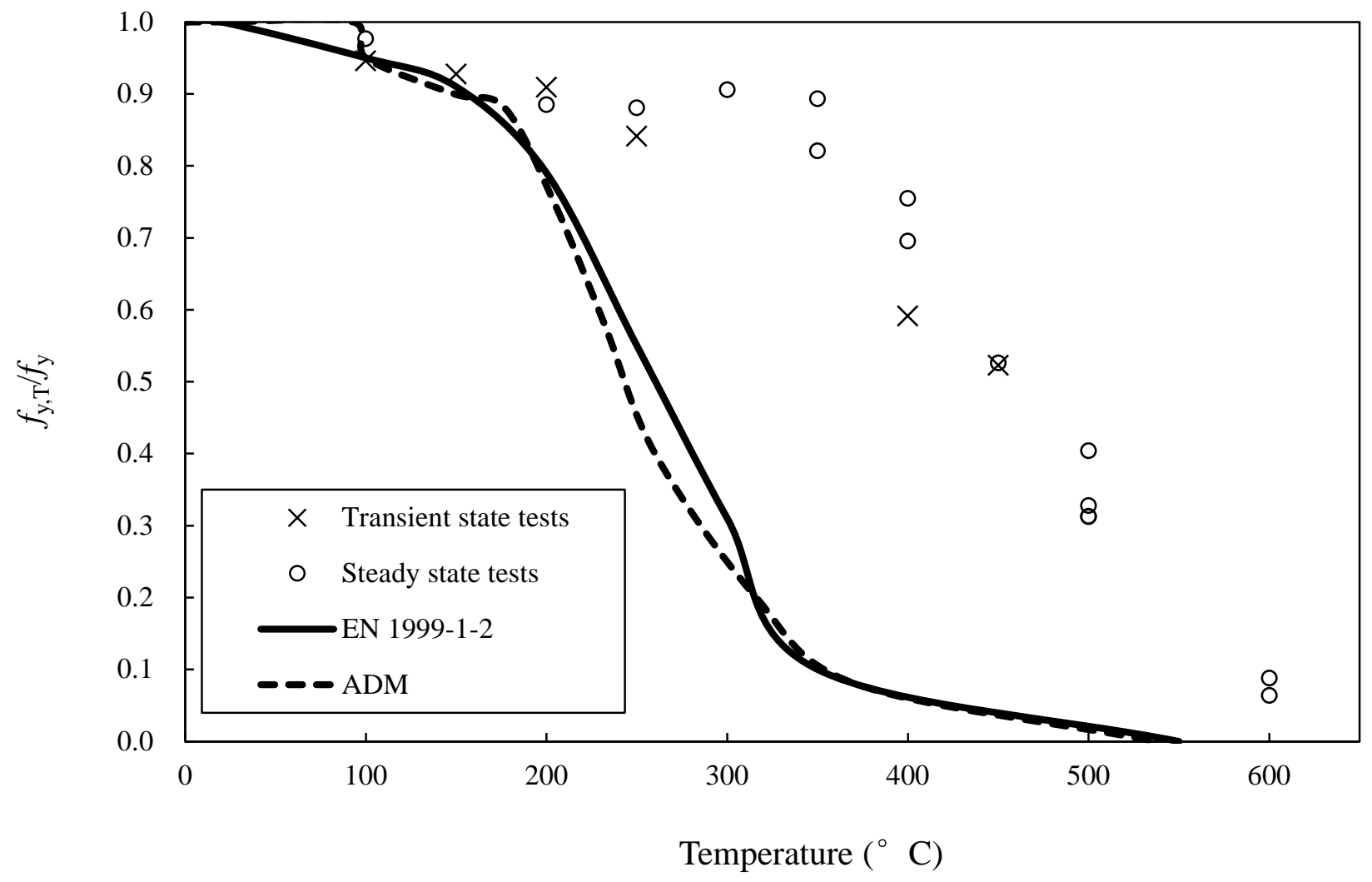

Fig. 6. Comparison of the yield stress obtained from design rules and test results. 


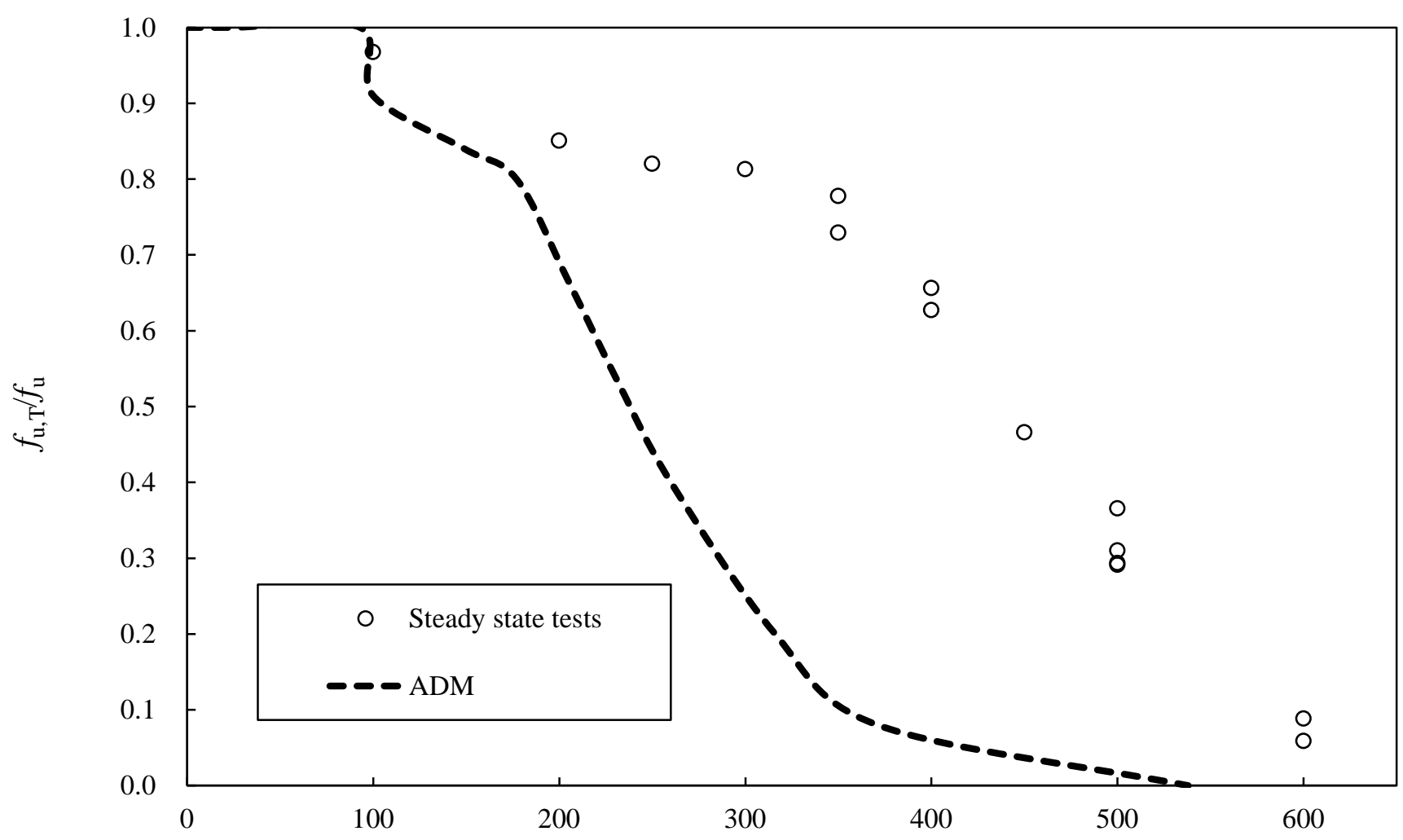

Temperature $\left({ }^{\circ} \mathrm{C}\right)$

Fig. 7. Comparison of the ultimate stress obtained from design rules and test results.

Table 4. Comparison of different design rules in predicting the reduction factors of material properties at elevated temperatures.

\begin{tabular}{|c|c|c|c|c|c|c|}
\hline $\begin{array}{l}\text { Test } \\
\text { methods }\end{array}$ & & $\frac{\left(E_{T} / E\right)_{t e s t}}{\left(E_{T} / E\right)_{A D M}}$ & $\frac{\left(E_{T} / E\right)_{\text {test }}}{\left(E_{T} / E\right)_{E N 1999}}$ & $\frac{\left(f_{y, T} / f_{y}\right)_{t e s t}}{\left(f_{y, T} / f_{y}\right)_{A D M}}$ & $\frac{\left(f_{y, T} / f_{y}\right)_{t e s t}}{\left(f_{y, T} / f_{y}\right)_{E N 1999}}$ & $\frac{\left(f_{u, T} / f_{u}\right)_{t e s t}}{\left(f_{u, T} / f_{u}\right)_{A D M}}$ \\
\hline \multirow{2}{*}{$\begin{array}{l}\text { Steady } \\
\text { state }\end{array}$} & Mean & 2.39 & 2.42 & 9.48 & 8.29 & 9.30 \\
\hline & $\mathrm{COV}$ & 0.628 & 0.590 & 0.797 & 0.609 & 0.700 \\
\hline \multirow{2}{*}{$\begin{array}{l}\text { Transient } \\
\text { state }\end{array}$} & Mean & 1.07 & 1.07 & 4.41 & 3.84 & --- \\
\hline & $\mathrm{COV}$ & 0.414 & 0.393 & 1.131 & 1.097 & --- \\
\hline
\end{tabular}

\section{CONCLUSIONS}

An experimental investigation of material properties of high strength aluminium alloy 6061-T6 at elevated temperatures has been presented. The test specimens were extracted from rectangular hollow sections of aluminium alloy. Tensile coupon tests using steady state test method at different temperatures ranged from 24 to $600^{\circ} \mathrm{C}$ were conducted. In addition, the transient state tests at different stress levels ranged from 0 to $220 \mathrm{MPa}$ were also conducted. Material properties including the Young's modulus, the yield stress, the ultimate stress and the ultimate strain at elevated temperatures were obtained. The test results obtained in this study were compared with design predictions by the American Aluminum Design Manual (ADM) as well as Eurocode EN 1999-1-2. In general, it is shown that both the ADM and EN 1999 provide rather conservative predictions to 
the Young's modulus, the yield stress and the ultimate stress of the high strength aluminium alloy at elevated temperatures.

\section{ACKNOWLEDGMENT}

The research work described in this paper was supported by a grant from The University of Hong Kong under the seed funding programme for basic research.

\section{REFERENCES}

[1] Yu, W. W. Cold-formed steel design. 3rd ed. New York: Wiley, 2000.

[2] Aluminum Association (AA), Aluminum design manual (ADM), Washington, DC, 2000.

[3] European Committee for Standardization (CEN), "Eurocode 9: Design of aluminum structures-Part 12: Structural fire design." BS EN 1999-1-2:2007, Brussels 2007.

[4] Rincona, E., Lopezb, H.F., Cisnerosa, M.M. and Manchac, H., "Temperature effects on the tensile properties of cast and heat treated aluminium alloy A319”, Materials Science and Engineering A 519:128-1402009, 2009.

[5] Shojaei, K., Sajadifar, S.V., Yapici and G.G. "On the mechanical behavior of cold deformed aluminum 7075 alloy at elevated temperatures”, Materials Science \& Engineering A, No.670, pp.81-89, 2006.

[6] Li, L. T., Lin, Y.C., Zhou, H.M. and Jiang, Y. Q., "Modeling the high-temperature creep behaviors of 7075 and 2124 aluminum alloys by continuum damage mechanics model”, Computational Materials Science, No.73, 72-78, 2003.

[7] Maximov, J.T., Duncheva, G.V., Anchev, A.P. and Ichkova M.D., "Modeling of strain hardening and creep behaviour of 2024T3 aluminium alloy at room and high temperatures", Computational Materials Science No.83, 381-393, 2014.

[8] Standard Association of Australia, Methods for the tensile testing of metals at elevated temperatures. AS 2291, Australian standard, 1979.

[9] American Society for Testing and Materials, Standard test methods for elevated temperature tension tests of metallic materials, ASTM E 21 - 09, West Conshohocken, USA, 2009. 